\title{
Studi Eksegesis Mengenai Kerajaan Mesias Menurut Yesaya 2:1-4
}

\author{
Farel Yosua Sualang \\ Sekolah Tinggi Teologi Injili Indonesia Yogyakarta \\ Korespondensi: sualangfarel@gmail.com
}

\begin{abstract}
Abstrak
Masalah utama mengenai maksud kata Ibrani שים "haggôyîm" dalam Yesaya 2:1-4 yang diartikan sebagai "bangsa-bangsa" memberikan suatu interpretasi yang berbeda-beda. Analisis mengenai "Pemerintahan Mesias menurut Yesaya 2:1-4" patut untuk dikaji dalam memerhatikan penggunaannya yang dijelaskan pada perjanjian lama dan perjanjian baru sebagai suatu tujuan penelitian dalam artikel ini. Pendekatan hermeneutika nubuatan, yang terdiri dari beberapa prosedur ataupun metode-metode yang dipakai untuk menjelaskan subjek yang diteliti. Jenis sastra nubuatan dalam Yesaya 2:1-4 memiliki struktur yang berbentuk nubuatan keselamatan sebagai metodologi dalam menafsirkan teks. Pemaparan dalam Yesaya 2:1-4 ingin menunjukkan suatu penyataan tentang Pemerintahan yang dipimpin oleh Sang Mesias yang terkait dengan kedatanganNya, PemerintahanNya, Warga KerajaanNya, pengenalan yang penuh akan Allah dan kedatanganNya. Hal ini dapat ditunjukan dengan ekspresi kedatangan Mesias, penjelasan tentang pusat pemerintahan Mesias, warga kerajaan Mesias (orang-orang Israel yang sudah diselamatkan), dampak-dampak pemerintahan Mesias, pengenalan penuh akan Allah dan dosa bangsabangsa dihakimi, dimana Ia akan menghakimi dunia dari tahta-Nya di Bait Allah.
\end{abstract}

Kata kunci: Yesaya, eksegesis, genre nubuatan, Kerajaan Mesias.

\begin{abstract}
The main problem regarding the meaning of the Hebrew word Eיד "haggôyîm" in Isaiah 2: 1-4, which is interpreted as "the nations" gives a different interpretation. The analysis of "the Messiah's reign according to Isaiah 2: $1-4 "$ is worth studying in regard to its use described in the old and new covenants as a research objective in this article. Hermeneutic prophetic approach, which consists of several procedures to explain the subject under study. The type of prophetic literature in Isaiah 2: 1-4 has the structure in the form of the prophecy of salvation as a methodology for interpreting this text. The presentation in Isaiah 2: 1.4 wants to show a revelation of the Government led by the Messiah related to His coming, His Government, Citizens of His Kingdom and His coming. This can be demonstrated by the expression of the coming of the Messiah, explanation of the central government of Messiah, the citizens of the Messiah's kingdom, the effects of Messiah's reign, the full knowledge of God and the sins of the nations being judged, where he will judge the world from His throne in the Temple.
\end{abstract}

Keywords: Isaiah, exegesis, prophetic genre, The Kingdom of Messiah. 


\section{PENDAHULUAN}

Kitab Yesaya dianggap sebagai bagian yang terpenting dari Perjanjian Lama. Hal ini terlihat antara lain dengan banyaknya kutipan yang diambil daripadanya dalam Perjanjian Baru: yang disebutkan namanya saja tidak kurang dari dua puluh satu kali, di samping banyaknya alusi dan referensi kepadanya. ${ }^{1}$

Yesaya banyak memberikan kumpulankumpulan khotbah yang dikumpulkan oleh nabi itu sendiri. Bahkan sesungguhnya, Nabi tersebut memberikan ungkapan-ungkapan tentang keagungan rumah Allah dan perluasan kekuasaanNya dalam Yesaya 2:1-4. Walaupun, Tuhan menghukum Israel dengan ketidaktaatannya, namun di tengah-tengah hukuman tersebut, Yesaya memberikan penghiburan kepada Israel. Yesaya menubuatkan waktu berkat yang besar bagi Israel dan Dunia dengan hadirnya Pemerintahan Mesias. Penelitian inilah yang mendorong untuk membahas pemerintahan Mesias yang berkaitan dengan nubuatan dalam Yesaya 2:1-4.

Analisis mengenai Pemerintahan Mesias dalam Yesaya 2:1-4 memiliki beberapa latar belakang masalah yang patut untuk dikaji. Ada 2 (dua) latar belakang masalah utama mengenai analisis Pemerintahan Mesias dalam Yesaya 2:1-4. Pertama, masalah mengenai maksud kata Ibrani הַוּוֹט "haggôyîm" yang diartikan sebagai "bangsabangsa." Bangsa-bangsa yang dijelaskan pada ayat ketiga merujuk kepada suatu alasan bahwa semua bangsa pergi ke gunung Yahweh (ay.3). Hal tersebut diperjelas kembali oleh Yesaya dengan ungkapan "sebab dari Sion" yang merujuk kepada semua bangsa-bangsa pergi ke Sion. Baik melalui perkataan תוֹרָה "tôrâ" yang diartikan sebagai pengajaran maupun kata דָָָָ "dābar" yang diartikan sebagai "firman." Kata tersebut merujuk bahwa baik "pengajaran" dan "firman" diberitahukan dari Yerusalem, baik ajaran

${ }^{1}$ Leon J. Wood, The Prophets of Israel (Malang: Gandum Mas, 2005), 440. universal yang dimaksudkan untuk semua orang, meskipun nasihat pribadi yang tidak sama untuk semua orang (mis.: Kesepuluh Firman), maupun nasihat pribadi yang tidak sama untuk semua orang (mis: perkara-perkara pribadi). Dalam hal ini beberapa penafsir mencoba untuk menafsirkan kapan penggenapan "pengajaran dari Sion akan terjadi kepada bangsa-bangsa." Derek Kidner mengatakan bahwa nubuat ini akan digenapi oleh gereja. ${ }^{2}$ Namun dari sisi yang lain, beberapa teolog menyatakan bahwa pemilihan atas orang-orang Yahudi merupakan suatu ketetapan atas bangsa pilihan Tuhan, sehingga barangsiapa yang memberkati mereka akan diberkati Tuhan. Oleh sebab itu, dari Ibukota Israel, yaitu Yerusalem, Tuhan sendirilah yang akan menjadi raja di seluruh dunia. ${ }^{3}$ Seorang penafsir harus memerhatikan dalam hubungan ayat-ayat ini pada pembicaraan tentang "Pemerintahan Mesias" yang perlu dikaji atas beberapa analisis-analisis pada Yesaya 2:1-4.

Kedua, Analisis mengenai "Pemerintahan Mesias menurut Yesaya 2:1-4" patut untuk dikaji dalam memerhatikan penggunaannya yang dijelaskan pada Perjanjian Lama dan Perjanjian Baru, sehingga artikel ini dapat memerhatikan cangkupan pemerintahan Mesias yang juga dijelaskan dalam konteks kitab nabi-nabi dan hubungannya dalam injil-injil ataupun surat-surat lainnya.

${ }^{2}$ Di sini, sama seperti dalam Mikha 4:1-5 yang hampir sama bentuknya, kelihatan keistimewaan Sion, bahwa Tuhan berdiam di dalamnya (band. Maz. 68:6-17), di mana puncakpuncak yang lebih tinggi nampak dengan penuh kecemburuan); dan ini adalah satu-satunya kemuliaan gereja. Derek Kidner, Tafsiran Alkitab Masa Kini 2 "Yesaya" (Jakarta: Yayasan Komunikasi Bina Kasih, 1985), 373.

${ }^{3}$ Achim Teshner, Rangkaian Visi Mutiara Kitab Yesaya (Jakarta: Yayasan Komunikan Bina Kasih, 1996), 29 


\section{METODE}

Artikel ini akan menggunakan kajian kualitatif dengan pendekatan hermeneutika nubuatan, ${ }^{4}$ yang terdiri dari beberapa prosedur ataupun metodemetode yang dipakai untuk menjelaskan subjek yang diteliti. Jenis sastra nubuatan dalam Yesaya 2:1-4 memiliki struktur yang berbentuk nubuatan keselamatan. ${ }^{5} \quad$ Jenis terhadap sub-genre ini mengidentifikasi pengharapan masa depan yang diumumkan, dan dalam hal ini, kembalinya raja Yehuda dan perkakas rumah Tuhan dari Babel. Namun begitu, pemaparan dalam Yesaya 2:1-4 ingin menunjukkan suatu penyataan tentang pemerintahan yang dipimpin oleh Sang Mesias.

Kajian terhadap jenis sastra nubuatan akan memerhatikan beberapa analisis, sehingga pemaparan terhadap analisis-analisis tersebut dapat membantu pekerjaan dalam karya ilmiah ini. Setidaknya, kajian ini memakai 5 (lima) analisis yang patut diperhatikan dalam kajian Yesaya 2:1-4. Pertama, analisis literal. Analisis ini akan dipakai untuk mencari arti kata yang penting dalam Yesaya 2:1-4 dari bahasa Ibrani ke dalam Indonesia. Namun begitu juga memerhatikan beberapa terjemahan-terjemahan yang lain. Dalam analisis literal ini, seorang penafsir mencoba melakukan pendekatan dengan mencari suatu "bahasa persamaan" yang memerhatikan situasi analogis, tetapi tidak mau membebani teks

${ }^{4}$ Dalam menganalisa Kitab Suci, para pakar mengelompokkan ragam sastra dalam Alkitab (contohcontoh genre sastra, seperti: Hukum, narasi, puisi, hikmat, Injil-injil, wacana logis, dan nubuatan), yang mana masingmasing genre sastra memiliki prosedur analisisnya tersendiri. Roy B. Zuck, Hermeneutik: Basic Bible Interpretation (Malang: Gandum Mas, 2014), 137-145. Contoh lain seperti penggunaan Genre Hikmat. Farel Y. Sualang, "Prinsipprinsip Hermeneutika Genre Hikmat Dalam Kitab Amsal: Suatu Pedoman Eksegesis". INA-Rxiv. May 9. https://osf.io/preprints/inarxiv/xmk6h/

${ }^{5}$ Dalam strukturnya, nubuatan keselamatan mirip dengan nubuatan bencana, namun isinya bersifat positif, bukan negative seperti yang terdapat dalam nubuatan bencana. William W. Klein, Craig Blomberg, dan Robert L. Hubbard, Introduction to Biblical Interpretation 2 (Malang: Literatur SAAT, 2013), 265. tersebut ke arah harafiah ataupun simbolis. ${ }^{6}$ Perlu diketahui bahwa Yesaya 2:1-4 merupakan salah satu teks mesianis Perjanjian Lama, sehingga isi mengenai ayat-ayat tersebut bukanlah murni simbolis karena mereka juga benar-benar merujuk kepada peristiwa yang akan datang. Ayat-ayat yang akan dibahas juga bukanlah benar-benar harafiah, karena mereka juga menjelaskan kesepadanan sejarah dan juga nubuatan Mesias yang langsung. ${ }^{?}$ Oleh sebab itu, nubuatan Yesaya 2:1-4 akan juga memerhatikan antara keterkaitan bagi Israel dan penggenapannya secara Israel yang memiliki hubungan terhadap penjelasan tentang "Pemerintahan Mesias."

Kedua, analisis konteks. Analisis ini akan terbagi menjadi dua yaitu analisis historis dan khusus. ${ }^{8} \quad$ Analisis konteks historis juga dipentingkan untuk mempelajari kembali peristiwa-peristiwa dan kondisi kehidupan religius Israel selama masa kehidupan nabi tersebut, serta mempelajari periode waktu tertentu, buku sejarah yang mengarahkan pembaca pada teks-teks krusial dalam Alkitab. ${ }^{9}$ Dari sisi yang lain, seorang penafsir harus memerhatikan konteks khusus. Konteks khusus akan memerhatikan sudut pandang dari setiap kata-kata, kalimat-kalimat, dan paragraf-paragraf sebelum ataupun sesudah dari yang akan dianalisis. ${ }^{10}$ Lebih dari itu, Seorang penafsir akan mencoba melihat hubungan antara Yesaya 2:1-4 dengan Mikha 4:1-5 sebagai konteks antar bagian kitab, bahkan hubungannya dalam seluruh Perjanjian Lama dan Perjanjian Baru.

Ketiga, analisis gramatikal. Analisis ini akan memerhatikan dari sudut pandang tata bahasanya, entah dalam kalimat, anak kalimat, atau frase yang

${ }^{6}$ Grant R. Osborne, Spiral Hermeneutika: Pengantar Komprehensif Bagi Penafsiran Alkitab (Surabaya: Momentum, 2012), 325.

${ }^{7}$ Ibid.

${ }^{8}$ Douglas Stuart, Gordon D. Fee, HermeneutikMenafsirkan Firman Tuhan Dengan Tepat (Malang: Gandum Mas, 2011), 173-175.

${ }^{9}$ William W. Klein, Craig Blomberg, dan Robert L. Hubbard, Introduction to Biblical Interpretation 2, 282-283.

${ }^{10}$ Tremper Longman III, Making Sense of the Old Testament (Malang: Literatur SAAT, 2012), 24. 
akan memengaruhi terhadap analisis terjemahan pada teks Yesaya 2:1-4. Dalam bagian ini, seorang penafsir akan memerhatikan persoalan-persoalan gramatikal pada bagian ini dengan memerhatikan sistem ejaan dan bagian-bagian kata yang memengaruhi makna kata tersebut. ${ }^{11}$

Keempat, analisis teologis. Hal ini akan dikaji oleh penulis dengan memerhatikan Yesaya 2:1-4 melalui hubungan tentang perjanjian Allah yang meliputi Perjanjian Lama dan Perjanjian Baru. Sehingga, analisis ini dapat memberikan sumbangan teologis dari perikop tersebut. Kelima, pada bagian terakhir analisis retoris patut untuk diperhatikan dalam kajian Yesaya 2:1-4. ${ }^{12}$ Penelitian retoris akan berusaha untuk mengerti logika sang penulis, gaya dan maksudnya. Seorang penafsir harus memerhatikan tekanan yang harus ditempatkan kepada (a) pola yang terdapat dalam unit sastra (b) cara-cara gaya bahasa individual yang menyokong dampak menyeluruh dari seluruh unit, (c) hubungan antara bagian-bagian keseluruhan. Bahkan lebih dari itu, analisis ini juga memerhatikan suatu perikop yang menuntut pengidentifikasian terhadap kiasan-kiasan dalam Yesaya 2:1-4.

\section{PEMBAHASAN}

\section{Konteks Kitab Yesaya}

Tema Yesaya adalah keselamatan. ${ }^{13}$ Lebih dari pada itu, nama Yesaya berarti "Yahweh keselamatan" menunjukkan tema ini. ${ }^{14}$ Kitab Yesaya dapat dibagi menjadi dua bagian: pasal 1-39 dan pasal 40-66. Paruh pertama dari kitab ini berfokus pada pembalasan Allah atas Yehuda, sedangkan babak kedua menampilkan pemulihan

\footnotetext{
${ }^{11}$ Douglas Stuart, Eksegese Perjanjian Lama (Malang: Gandum Mas, 2012), 29.

${ }^{12} \mathrm{Ibid}, 134-135$.

${ }^{13} \mathrm{G}$. L. Archer, A Survey of Old Testament Introduction( Chicago IL: Moody Press, 1994), 63.

${ }^{14} \mathrm{~F}$. Delitzsch, Isaiah: Commentary on the Old Testament, jil. 7. Peny., C. F. Keil, dan F. Delizsch (Peabody MA: Hendrikson, 1996), 45.
}

Allah bagi Yehuda. ${ }^{15}$ Bagian pertama berfungsi sebagai gambaran dari kitab Yesaya. Ini dimulai dengan kecaman Yehuda (pasal 1-23) dan berakhir dengan janji restorasi Yehuda (pasal 24-31). Struktur bagian pertama menunjukkan tema dari dua bagian buku ini.

\section{Konteks Dekat}

Konteks dekat sebelum pasal 2 (dua) adalah konteks seri pertama dari sabda-sabda Tuhan dalam pasal 1:2-31. Dalam bagian ini, penulis kitab memperkenalkan kitabnya melalui kumpulan sabda-sabda yang memberitahukan pelanggaran Yehuda dan meratapi pengrusakan negeri itu karena perang (1:24-31). Ketidakpercayaan Yehuda kepada Yahweh telah menurunkan derajat bangsa itu dari status manusia ke status binatang-tidak, bahkan lebih rendah lagi, karena sebagai negeri yang dihancurkan oleh perang, Yehuda seperti satu tubuh penuh dengan memar, luka ngeri, bekas pukulan, dan luka-luka berdarah, sehingga tidak ada lagi tempat untuk pukulan atau cambukan lain (1:5-9). Waktu dari sabda yang pertama sering disamakan dengan penyerbuan Sanherib pada tahun 701 SM. Menurut kisahnya, ia mengepung dan merebut empat puluh enam kota-kota berkubu dan banyak kota kecil, tetapi Yerusalem terluput (2 Raj. 18:13 - 19:36). ${ }^{16}$ Untuk memperkuat gambaran kemurtadan Yehuda yang memalukan, sabda yang kedua menghubungkan para pemimpin dan rakyat dengan Sodom dan Gomora (1:10-31), meratapi sistem keagamaan bangsa yang hina dan memanggil mereka untuk bertobat. ${ }^{17}$

${ }^{15}$ J. A. Martin, Isaiah: The Bible Knowledge Commentary Old Testament, peny., J. F. Walfoord, dan R. B. Zuck (Wheaton: Victor Books, 1994), 1032.

${ }^{16}$ George Buchaman Gram, A Critical and Exegetical Commentary on the Book of Isaiah I-XXVII (Edinburgh: T\&T Clark, 1912), 12; Oto Kaiser, Isaiah 1-12, a Commentary (Philadelphia: Westminster, 1972), 9.

${ }^{17}$ C. Hassel Bullock, Kitab Nabi-nabi Perjanjian Lama (Malang: Gandum Mas, 2002), 179. 
Seri sabda yang kedua, yakni pasal 2:1-4 dan 4:1-4 menggambarkan panorama yang segar di masa depan bagi Yehuda dan Yerusalem yang dalam pasal sebelumnya mengerikan. Bagian ini (2:1-4 dan 4:16) berfungsi sebagai bookends untuk bagian pertama dari pasal 1-39. Keduanya mengacu pada kemuliaan masa depan Yerusalem yang menggolongkan peringatan dari penghakiman. ${ }^{18}$ Dalam bagian kedua, setelah bernubuat tentang masa depan yang gemilang dari Yerusalem dalam ayat 1-4, Yesaya menantang Israel untuk menaati Tuhan dalam ayat 5. Kemudian, dalam sisa bagian kedua dan melalui pasal 3, Yesaya menubuatkan penghakiman. Dengan demikian, dalam beberapa bab pertama dari Yesaya, gambar kontras hukuman untuk dosa dan pemulihan yang dijanjikan saling terjalin.

\section{Konteks Sejarah}

Invasi Asyur ke Yehuda pada tahun 701 BC mungkin peristiwa bersejarah terkemuka sampai dengan tulisan Yesaya. ${ }^{19}$ Sanherib, raja Asyur, sedang bergerak menuju Yerusalem, ketika Malaikat Tuhan membunuh 185.000 orang Asyur (2 Raja-raja 18:13-19:35). Sanherib kemudian berangkat dan kembali ke Niniwe (2 Raja-raja 19:16). Yesaya mengacu kepada invasi Yehuda dan perlindungan Allah atas Yerusalem dalam 1:8-9. Jika Yesaya 2:1-4 ditulis selama ini, nubuatannya mengenai masa depan Yerusalem yang gemilang akan melukis kontras dan harapan Yerusalem pada zamannya.

\section{Jenis Genre Nubuatan}

Jika memerhatikan kisah-kisah nabi dalam Perjanjian Lama, maka para pembaca dapat memerhatikan dimana bangsa Israel secara menyedihkan tersesat dalam penyembahan berhala. Namun begitu, Allah mengutus nabi-nabi untuk mengumumkan rencanaNya bagi umatNya.

${ }^{18}$ H. C. Leupold. Exposition of Isaiah. Jil 1 (Grand Rapids: Baker House, 1971), 73.

${ }^{19}$ Bullock, Kitab Nabi-nabi Perjanjian Lama, 179.
Meskipun proklamasi mereka seringkali menghasilkan "ramalan" (yakni, prediksi tentang masa depan), tetapi isi utamanya berupa "pemberitahuan awal" (yakni, pengumuman tentang hukuman ilahi yang segera terjadi pada masa kini atau dalam waktu dekat). ${ }^{20}$ Hubungannya dalam Yesaya 2:1-4, teks ini memberikan suatu proklamasi dalam tulisan-tulisan Yesaya. Teks tersebut merupakan kreativitas kesusasteraan yang dihasilkan baik oleh Yesaya dalam menyusun tulisan-tulisan tersebut. Agar dapat memahami Yesaya 2:1-4, seorang penafsir dituntut untuk memahami secara keseluruhan ayat-ayat yang terkandung didalamnya - narasi dan puisi - untuk menentukan apa yang dikatakan mereka, dan mengapa mereka mengungkapkannya dengan cara tersebut. $^{21}$

Nubuatan Yesaya 2:1-4 masuk di dalam kelompok/jenis nubuatan keselamatan. ${ }^{22}$ Ciri khas dari sub-genre nubuatan keselamatan adalah pemarapan dari strukturnya, walaupun memiliki kemiripan dengan nubuatan bencana, namun isinya bersifat positif, bukan negatif seperti yang terdapat dalam nubuatan bencana. ${ }^{23}$ Struktur dari sub-genre nubuatan keselamatan pada Yesaya 2:1-4 dapat ditunjukan seperti berikut:

${ }^{20}$ William W. Klein, Craig Blomberg dan Robert L. Hubbard, Introduction to Biblical Interpretation 2 (Malang: Literatur SAAT, 2013), 262.

${ }^{21}$ Pendekatan kami berdasarkan kenyataan kesusastraan bahwa kita mengakses kitab para nabi hanya lewat kitab-kitab yang menggunakan nama para nabi sebagaimana yang terdapat dalam Alkitab masa kini, kitabkitab yang mungkin saja disuntingkan oleh orang lain. Namun kami berasumsi bahwa, sama seperti kitab-kitab Injil mengungkapkan ipsis-sima vox ("suara asli") Yesus, demikian juga kitab para nabi tetap mengungkapkan "suara asli" dari para nabi. Oleh sebab itum kami melewatkan genre kesusastraan utama dari "kitab nubuatan" untuk memberikan fokus atas sebuah contoh subgenre di antara apa yang dinamakan Sweeney sebagai "ucapan nubuatan." Marvin Sweeney, Isaiah 1-39 with an Introduction to Prophetic Literature (Michigan: William B. Eerdmans Publishing Company, 1996), 10-15.

${ }^{22}$ Ibid, 98.

${ }^{23}$ William W. Klein, Craig Blomberg dan Robert L. Hubbard, Introduction to Biblical Interpretation 2, 262. 


\begin{tabular}{|l|l|}
\hline \multicolumn{2}{|c|}{ Struktur dari sub-genre nubuatan keselamatan } \\
Fesaya 2:1-4 \\
\hline $\begin{array}{l}\text { Formula } \\
\text { pembawa berita }\end{array}$ & $\begin{array}{l}\text { Firman itu yang telah dilihat } \\
\text { kepada Yesaya anak Amos atas } \\
\text { Yehuda dan Yerusalem. }\end{array}$ \\
\hline Prediksi & $\begin{array}{l}\text { Akan terjadi pada hari-hari } \\
\text { yang ditetapkan itu: gunung } \\
\text { rumah TUHAN seperti kepala } \\
\text { diantara gunung-gunung dan } \\
\text { akan menjulang tinggi di atas } \\
\text { bukit-bukit, dan semua bangsa } \\
\text { akan beriring-iringan ke sana. }\end{array}$ \\
\hline Penjelasan & $\begin{array}{l}\text { Dan banyak bangsa-bangsa } \\
\text { akan berjalan dan berkata: } \\
\text { "berjalanlah, kita akan pergi ke } \\
\text { Gunung Tuhan, ke rumah } \\
\text { Allah Yakub. Dan Dia akan } \\
\text { mengajar kita tentang jalan- } \\
\text { jalanNya, dan supaya kita } \\
\text { berjalan pada jalan-Nya. Sebab } \\
\text { dari Sion akan keluar Taurat } \\
\text { dan firman Allah dari } \\
\text { Yerusalem." }\end{array}$ \\
\hline Penekanan ulang & $\begin{array}{l}\text { Dia akan menjadi hakim } \\
\text { diantara bangsa-bangsa dan } \\
\text { Dia akan menghukum banyak } \\
\text { bangsa-bangsa; dan mereka } \\
\text { akan mengalahkan dengan } \\
\text { pedang-pedang mereka ke } \\
\text { dalam mata pajak dan tombak- } \\
\text { tombak mereka menjadi pisau } \\
\text { pemotong dahan; bangsa- } \\
\text { bangsa tidak akan mengangkat } \\
\text { pedang kepada bangsa dan } \\
\text { mereka tidak akan belajar lagi } \\
\text { perang. }\end{array}$ \\
\hline
\end{tabular}

Dalam hal ini, Yesaya 2:1-4 merupakan bagian dari sub-genre nubuatan keselamatan yang mencatumkan unsur-unsur tambahan yang dijelaskan dengan panjang lebar, dan menunjukkan sebuah susunan yang bervariasi atas komponen-komponennya. Salah satu tujuan dari nubuatan ini adalah untuk mengidentifikasi pengharapan masa depan yang diumumkan mengenai "pemerintahan Mesias dan dalam hal ini adalah Yerusalem sebagai pusat dari pemerintahan Mesias itu sendiri.”

\section{Hubungan Yesaya 2:1-4 dengan Mikha 4:1-3}

Dalam beberapa hal kecil Yesaya 2:2-4 identik dengan Mikha 4:1-3. ${ }^{24}$ Sejak Yesaya dan Mikha melayani bersama-sama dari sekitar $750 \mathrm{SM}$ sampai 680 SM di Yerusalem dan Yehuda, pertanyaan tentang penulis aslinya akan muncul. ${ }^{25}$ Apakah Yesaya mengutip Mikha?

Ada bukti bahwa Mikha adalah penulis asli. Pertama, Mikha mengatakan "tegak/kuat" dan "menjulang tinggi" (Mik. 4:3) tidak nampak seperti penambahan, melainkan agak diabaikan oleh Yesaya. ${ }^{26}$ Kedua, Mikha 4:1-3 cocok dengan 3:9-12, sedangkan Yesaya 2:1-4 tidak mengalir dengan baik dari konteks sebelumnya. ${ }^{27}$ Ketiga, teks Mikha adalah dianggap sebagai superior, berdasarkan ruang lingkup perbedaan tekstual dari kedua ayat tersebut. ${ }^{28}$

Ada bukti yang sama bahwa Yesaya adalah penulis asli. Pertama, frase "sebab mulut Tuhanlah yang telah mengatakannya" hanya ditemukan dalam kitab Yesaya (1:20, 40:5, 58:14) kecuali untuk penggunaannya di Mikha 4:4. ${ }^{29}$ Kedua, Mikha mungkin telah diperkuat teks asli Yesaya dengan menambahkan ayat $4 .^{30}$ Ketiga, Motyer berpendapat pembukaan Mikha adalah biasa, jika dibandingkan dengan Yesaya yang biasanya styling opening. ${ }^{31}$ Keempat, variasi Mikha menunjukkan

\footnotetext{
${ }^{24}$ Perbedaan utama di dalam penggunaan kata-kata "nations" and "peoples" dan Mikha menambahkan katakata "strong" dan "afar off" dalam pasal 4:3.

${ }^{25}$ Pelayanan Yesaya tertanggal dari Yesaya 1:1. Pelayanan Mikha tertanggal dari Mikha 1:1.

${ }^{26} \mathrm{~J}$. P. Lange, Isaiah: Commentary of The Holy Scriptures, (Grand Rapids: Zondervan, 1877), 4.

${ }^{27}$ B. K. Waltke, Obadiah, Jonah, Micah, Tyndale Old Testament Commentary (Downers Grove: IVP, 1988), 171.

${ }^{28} \mathrm{Ibid}$.

${ }^{29} \mathrm{G}$. W. Grogan, Isaiah, The Expositor's Bible Commentary, jil. 6., peny. F. Gaebelein (Grand Rapids: Zondervan, 1978), 34.

${ }^{30}$ Leupold, Exposition of Isaiah, 75.

${ }^{31} \mathrm{~J}$. Alec Motyer, The Prophecy of Isaiah, dalam Analysed Bible, (Downer Grove IL: IVP, 1993), 53.
} 
bahwa ia bebas mengutip Yesaya. Misalnya, Mikha menambahkan konjungsi "dan" (?) sebelum kalimat "ke rumah dari Allah Yakub" di 4:2.32 Karena bukti-bukti menunjukkan salah seorang nabi biasa saja dalam penulis asli, penulis lebih menyetujui pernyataan Feinberg dimana dengan tepat ia menyimpulkan bahwa, "itu adalah inspirasi dari Roh Kudus, yang menjamin kita memiliki pikiran Allah dalam dua kasus." ${ }^{33}$

Masa depan gemilang Israel yang disajikan di dalam ayat-ayat ini sangat kontras dengan kondisi bangsa pada zaman Yesaya yang dijelaskan dalam pasal 1. Nubuat yang dicatat dalam bagian ini hampir identik dengan nubuatan yang muncul dalam Mikha 4:1-3 (lih. Mzm. 2:46). Mungkin Yesaya mengutip Mikha di sini, atau Mikha mengutip Yesaya, atau keduanya mengutip nabi lain. ${ }^{34}$

Yesaya 2:1-4 merupakan gambaran tentang masa depan yang mulia dari Yerusalem, saat Mesias memerintah dalam milenium, dalam tiga gambaran. Gambaran pertama tentang sketsa mengenai saat masa depan pemerintahanNya (ayat. 1-2a). Kedua, mengenai lokasi pemerintahan Kristus (ayat. 2b-3a). Ketiga, gambaran tentang manfaat dari pemerintahanNya (ayat 3b-4).

\section{Saat Pemerintahan Mesias (2:1-2a)}

Yesaya 2:1 berfungsi sebagai pengantar untuk sisa ayat berikutnya. ${ }^{35}$ Dalam ayat ini, Yesaya secara supranatural "melihat" חדזT "hāazāh" dan "berkata” דָָרָר "dābar." Itu adalah nubuatan "tentang Yehuda dan Yerusalem." Kata הָדר "haddā $\underline{b} \bar{a} r " ~ m e n u n j u k k a n$ bahwa ini adalah nubuatan yang baru tentang Yehuda dan Yerusalem. Penggunaan kata ini di sini tidak

\footnotetext{
${ }^{32} \mathrm{Ibid}$.

${ }^{33} \mathrm{C}$. Feinberg, The Minor Prophets, (ChicagolL: Moody Press, 1990), 167-168.

${ }^{34}$ F. Delitzsch, Isaiah: Commentary on the Old Testament, jil. 7. Peny., C. F. Keil, dan F. Delizsch (Peabody MA: Hendrikson, 1996), 111.

${ }^{35}$ Ayat 1 ditulis dalam prosa, sementara ayat 2-4 ditulis sebagai struktur puisi.
}

memiliki koneksi langsung dengan peristiwa yang dibicarakan Yesaya sebelumnya. Ini menandakan sesuatu yang baru. Dalam pasal sebelumnya istilah "visi" digunakan Yesaya 2:1, tetapi maknanya secara substansial sama. Istilah דרך "dābar " ("firman") menunjukkan suatu "perintah, janji, ajaran, sebuah nubuatan, wahyu, pesan dan atau sesuatu." Di sini artinya bahwa Yesaya menubuatkan "kejadian masa depan" tertentu atau hal-hal yang akan terjadi berkaitan dengan Yehuda dan Yerusalem.

Yesaya mulai ayat 2 tiba-tiba dengan kata רזדז "wahāyāh" ("dan akan terjadi”). Ketiba-tibaan ini memberikan kekuatan pada kata masa depan. ${ }^{36}$ Selanjutnya, hubungan kata dengan ayat 1 menyebabkannya untuk menandakan waktu atau saat masa depan. ${ }^{37}$

Peristiwa-peristiwa yang dinubuatkan Yesaya

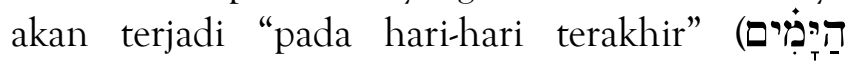
16 kali dalam Perjanjian Lama. Menurut C. F. Keil dan F. Delitzsch, "frase ini selalu digunakan dalam pengertian eskatologis. Tidak pernah mengacu pada perjalanan sejarah segera setelah saat itu, tetapi selalu menunjukkan titik jauh dalam sejarah hidup-titik ini terletak dari cakrawala pembicara." 38

"Hari-hari terakhir" adalah ungkapan yang menggambarkan waktu yang jauh dari perpektif nabi. Bahasa Ibrani memandang sejarah sebagai rangkaian hari, hari-hari hidup mereka. Judul Kitab Tawarikh berarti harafiah adalah "kata-kata dari hari-hari." Ketika hari ini terakhir, di bagian terakhir mereka, sejarah manusia di muka bumi ini akan terakhir. Orang Kristen Perjanjian Baru menerapkan istilah ini pada kedatangan Mesias

\footnotetext{
${ }^{36}$ E. J. Young, The Book of Isaiah, Jil. 3 (Grand Rapids MI: William B. Eerdmans, 1996), 96.

${ }^{37}$ Walkte mengklasifikasikan semua ayat pertama temporal adverbial konstruksi. Ketika kontruksi ini diikuti oleh וּזָדיi itu menandakan masa depan waktu. B. K. Waltke, dan M. O'Connor, An Introduction to Biblical Hebrew Syntax (Winona Lake IN: Eisenbrauns, 1990), 539.

${ }^{38} \mathrm{C}$. Keil dan F. Delitzsch, Isaiah, dalam Commentary
} 109 
(Kis. 2:17; Ibr. 1:2, Yak. 5:3, 1 Pet. 1:5; 1Pet. 1:20; 2 Pet. 3:3, 1 Yoh. 2:18). Di sini, "hari-hari terakhir" itu harus mengacu pada kedatanganNya yang kedua, karena kondisi ini tidak mengikuti kedatanganNya yang pertama. ${ }^{39}$

Mereka melihat kedatangan Mesias memberikan karakter, keagungan, dan kebahagiaan pada waktu mendatang. Oleh karena itu, ekspresi kedatangan Mesias terutama zaman Mesias, sering digunakan dalam Perjanjian Lama dan Perjanjian Baru untuk menunjuk saat atau waktu. Lihat Kisah Para Rasul 2:17; bandingkan Yoel 2:28; Ibrani 1:2; 1 Petrus 1:5, 20; 1 Yohanes 2:18, kejadian 49:1; Mikha 4:1; Ulangan 4:30; Yeremia 48:47; Daniel 11:28. ${ }^{40}$

Ekspresi selanjutnya dalam ayat 2 menjelaskan bahwa masa ini tidak bisa ditafsirkan selain mengacu kepada saat pemerintahan Mesias yang akan datang. Masa Patriarki dan dispensasi di bawah Musa telah berlalu, sedangkan dispensasi akhir yakni Kerajaan Mesias akan diwujudkan "pada hari-hari terakhir."

Peristiwa yang terjadi di masa depan ini dapat dibagi dalam dua kelmpok. Kelompok pertama berfokus pada kedamaian dan kemakmuran masa depan. ${ }^{41}$ Yesaya 2:2 dan Mikha 4:1 termasuk dalam kategori ini. Kelompok kedua berfokus pada penghakiman dan peperangan di masa depan. $^{42}$ Di dalam LXX, frase "pada hari-hari

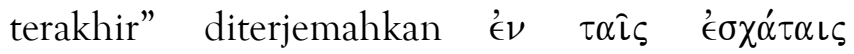

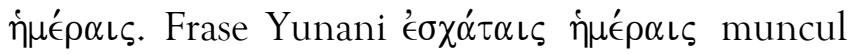
tiga kali dalam Perjanjian Baru (Kis. 2:17; 2 Tim. 3:1; dan Yak. 5:3).

Kisah Para Rasul 2:17 berbicara tentang pencurahan Roh kudus sebagai berkat pada masa depan. Oleh karena itu, "hari-hari terakhir"

\footnotetext{
${ }^{39}$ John H. Sailhamer, Evidence from Isaiah 2 in A Case for Premillennialism: A New Consensus (Chicago: Moody Press, 1992), 79-102.

${ }^{40}$ Albert Barnes, Barnes' Note on the Old Testament (Parsons technology, Inc. Cedar Rapids, Iowa. Electronil Edition STEP Files Copyright (C) 1999).

${ }^{41}$ Kejadian 49:1; Bilangan 24:14; Yehezkiel 38:8; dan Hosea 3:5.

${ }^{42}$ Ulangan 4:30; 31:29; Yeremia 23:20; 30:24;48:47; 49:39; Yehezkiel 38:16; Daniel 2:28; 8:19 dan 10:14.
}

dinubuatkan dalam Perjanjian Lama dan itu masih masa depan di dalam Perjanjian Baru. Poin frase tersebut adalah masa depan, tetapi tidak ada tempat yang tetap dalam waktu yang spesifik. Nubuat Alkitab lainnya, seperti yang terdapat dalam kitab Wahyu, butuh pemahaman yang lebih baik bagaimana "hari-hari terakhir" secara kronologis sesuai dengan waktu-waktu terakhir.

Wahyu 20:1-6 memberikan bingkai waktu tentang pemerintahan Kristus di masa depan dalam milenium, yaitu sebuah masa penuh kedamaian dan kemakmuran. Millenium yang sebelumnya diikuti tribulasi (Why. 6-19) dan mendahului langit baru dan bumi baru (Why. 2122). Banyak ayat dalam Yesaya, termasuk pasal 2:14, digenapi secara mendatail dalam kerajaan Milenium (Yes. 9:6-7, 11:1-10, 40:1-11, 61:4-11, 62:1-12, 65:17-25). Jadi, frase "pada hari-hari terakhir" dalam konteks Yesaya 2:1-4 mengacu kepada waktu pemerintahan milenial Kristus di masa depan.

\section{Pusat Pemerintahan Mesias (2:2b-3a)}

Pusat pemerintahan Mesias terkonsentrasi di Yerusalem. Kota ini akan menjadi pusat ibadah untuk dunia. Pada hari-hari terakhir "gunung rumah TUHAN akan didirikan” (ay.2b). Gunung yang menjadi tempat Rumah Tuhan dibangun menunjuk pada gunung Moria, yang disebut gunung rumah TUHAN. Gunung dimana Bait Allah didirikan akan menjadi objek yang akan mengekspresikan ibadah umum dari Allah yang benar. Dan karenanya, gunung ini akan diangkat lebih tinggi dari semua bukit-bukit atau gununggunung lain. Menyembah Allah yang benar akan menjadi obyek begitu mencolok untuk dilihat oleh semua bangsa dan begitu mencolok di mana semua bangsa akan meninggalkan benda lainnya karena tertarik oleh kemuliaan menyembah Allah yang benar.

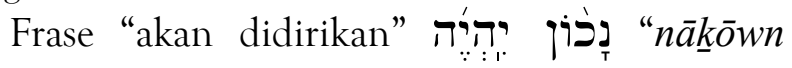
yihyeh" tidak hanya bersifat nubuatan dari peristiwa tertentu yang akan terjadi di masa depan, tetapi menekankan kepastian atau permanen. 
Young berpendapat bahwa seharusnya tidak diterjemahkan sebagai pasif di masa depan. Tujuannya adalah menunjukkan bahwa itu adalah suatu peristiwa yang sudah terjadi dalam progress waktu (seperti gereja). Argumennya adalah sintaksis dan bertumpu pada penggunaan ידיה (2) "yihyeh" ("akan") dengan pasif partisip נכוֹן "nāksowwn" ("didirikan"). ${ }^{43}$ Tetapi, Sailhamer menentang pandangan Young dengan menyatakan bahwa penggunaan "akan didirikan" dalam 1 Tawarikh 17:14 harus berarti peristiwa di masa depan dan oleh karena itu, harus diartikan sama dengan Yesaya 2:2a ini. ${ }^{44}$

Hal Spesifik yang didirikan di gunung adalah

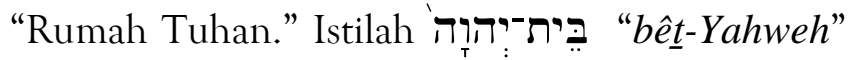
("Rumah Tuhan") dipakai 175 kali dalam Alkitab dan mengacu pada Tabernakel atau bait Allah setiap kali digunakan. Dengan demikian, yang ada dalam pikiran Yesaya adalah sebuah Bait Allah literal. Yehezkiel 40:43 menggambarkan tentang Bait Allah milenium. Yehezkiel 43:12 secara khusus menggambarkan lokasi sebagai di atas gunung. Juga ayat 3 mengacu kepada orang banyak yang mengatakan "mari, kita naik."

Secara khusus, banyak orang akan naik "ke gunung TUHAN, ke rumah Allah Yakub" (ay.3). Karena nubuat berhubungan dengan Yerusalem, maka Yesaya bernubuat bahwa bait Allah akan dibangun di Yerusalem, di atas gunung. ${ }^{45}$ Bahkan, keunggulan Bait Allah di gunung Yerusalem adalah tema yang berjalan di seluruh kitab

\footnotetext{
${ }^{43}$ Young, Isaiah, vol 1, 100.

${ }^{44} \mathrm{~J}$. H. Sailhamer, "Evidence from Isaiah 2", in A Case for Premillennialism: A New Concensus, D. K. Campbell, and J. L Townsend, eds, Chicago IL: Moody Press, 1992, 87.

${ }^{45}$ Di dalam BHS (Biblica Hebraica Stuttgartensia, $2^{\text {nd }}$ edn, Karl Elliger, and Wilhelm Rudolph, eds, Stuttgat Ger: Deutsche Bibelgesellschaft, 1977), Masoreteks mencatat bahwa frase אֶל-ה ("the mountain”) muncul 16 kali dalam Perjanjian Lama. 15 kali penggunannya mengacu kepada gunung karmel. Ini sangat signifikan karena gunung Karmel merupakan sebuah gunung yang riil. Jadi, frasa yang sama digunakan di sini dalam Yesaya, itu dapat menjadi bukti bahwa ini mengacu pada gunung yang riil. BHS, 677 .
}

Yesaya ${ }^{46}$ Bait Allah di gunung akan "lebih tinggi

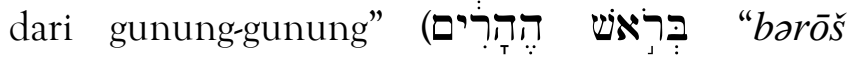
hehārîm"). Para penerjemah telah menafsirkan kata ברֵאי "borōs" dalam ayat ini setidaknya dalam dua cara: "puncak" dan "di atas," dengan masing-masing terjemahan yang menawarkan penekanan yang berbeda-beda.

Pertama, istilah "gunung" kadang-kadang merupakan simbol kerajaan, negara, kekuasaan, atau aturan lain dalam tulisan-tulisan nabi (misalnya, Dan. 2:35, 44-45; Am. 4:1; Why. 17:911). Orang di dunia kuno juga menganggap gunung sebagai rumah para dewa. Jika Yesaya menggunakan "gunung" sebagai sebuah figure of speech, itu berarti bahwa Israel dan Tuhan mereka akan menjadi yang paling ditinggikan di bumi akhirnya. Kasus ini akan terjadi selama pemerintahan Mesias di dunia.

Kedua, bagaimanapun, referensi untuk "gunung rumah Tuhan," kemungkinan besar menunjukkan bahwa nabi memiliki arti yang lebih literal dalam pikiran. Ini berarti bahwa gunung di masa Bait Allah didirikan akan didorong lebih tinggi di ketinggian. Hal ini mungkin terjadi (lih. Yeh. 40:2; Za. 14:4, 10), tetapi implikasi utama tampaknya bahwa Israel dan Yahweh akan ditinggikan di dunia. ${ }^{47}$

Martin juga percaya bahwa "gunung-gunung" (הֶהָרְים "hehārîm") bisa merepresentasikan "kerajaan" karena digunakan dengan cara itu di dalam Daniel 2:35. ${ }^{48}$ Konteksnya sangat menentukan bagaimana dua kata ini harus diterjemahkan. Sailhamer dengan sangat baik berpendapat bahwa penggunaan Yesaya tentang

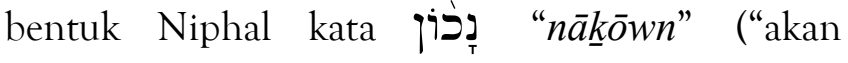
didirikan”) menunjukkan penciptaan pegunungan baru. Ia mendukung hal ini dengan menunjukkan kegunaannya dalam seluruh Mazmur dan literaturliteratur hikmat, terutama dalam konteks yang berurusan dengan tema-tema penciptaan. ${ }^{49}$ Kata

${ }^{46}$ Yesaya 11:9;25:6-7; 27:13; 30:29; 56:7; 57:13; 65:11, 25;66:20. Martin, "Isaiah", 1036.

${ }^{47}$ Expository Notes of Thomas Constable.

${ }^{48}$ Martin, "Isaiah", 1037.

${ }^{49}$ Sailhamer, "Evindence from Isaiah 2", 88. 


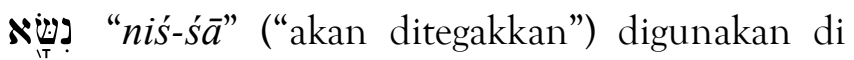
tempat lain dalam Yesaya $(2: 14 ; 30: 25 ; 57: 7)$ untuk menggambarkan gunung-gunung dan bukti-bukit

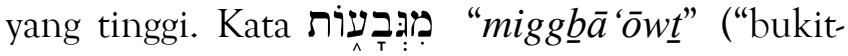
bukit”) sering digunakan dalam struktur paralel sebagai sinonim untuk "gunung-gunung" dalam bahasa puisi ibrani. ${ }^{50}$

Frase "dan akan ditegakkan di atas bukitbukit" adalah penyajian kembali puisi "lebih tinggi

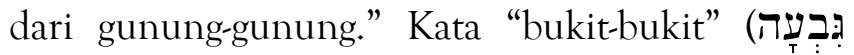
"gib 'ôf') tidak pernah dalam Yesaya untuk mewakili "kerajaan." 51 Selain itu, frase "gunung rumah Tuhan” mengacu pada gunung Bait Allah. Kata "gunung-gunung" (הָּרָּים "hehārîm") harus diterjemahkan secara konsisten di seluruh bagian sebagai gunung literal (apakah tunggal atau jamak). Berdasarkan bukti ini, terjemahan dan interpretasi terbaik untuk frase ini adalah literal "lebih tinggi dari gunung-gunung." 52

\section{Warga Kerajaan Mesias (2c-3a)}

Jika dipikirkan secara negatif, orang-orang yang belum diselamatkan tidak ada yang akan masuk dalam kerajaan Mesias ini (Yes. 35; Yer. 31:33, 34; Yeh. 20;37, 38; Za. 13:9; Mat. 18:3; 25:30, 46; Yoh. 3:3). ${ }^{53}$ Jika dipikirkan secara positif, warga kerajaan Mesias ini akan terdiri dari; (1) orangorang Israel yang sudah diselamatkan (mereka dihubungkan dengan Allah melalui perkawinan

${ }^{50}$ Contoh termasuk Yesaya2:14, 30:17, 30:24, 31:4, $30: 25,31: 4,40: 4,40: 12,41: 15,42: 15,54: 10,55: 12$, dan 65:7. BDB (F. Brown, The New Brown, Driver, and Briggs Hebrew and English Lexicon of The Old Testament, Lafayette LA: Associated Publishers \& Authors, 1981), 149.

${ }^{51}$ Kata "bukit-bukit" digunakan 14 kali dalam kitab Yesaya, dan masing-masing penggunannya and in each use an elevated geography is meant. In Fact, is 31:4 seems to refer to the temple mountain as a "hill."

${ }^{52}$ Bagian Kitab Suci lain menunjukkan bahwa Bait Allah di gunung akan lebih tinggi secara fisik daripada semua gunung lainnya di bumi. Pada semua akhir penghakiman selama kesusahan akan meratakan geografi bumi (Why. 16:20. Ketika Kristus datang kembali, Yerusalem akan naik (Za. 14:10).

${ }^{53}$ H. L. Wilmington, Eskatologi (Malang: Gandum Mas, 2003), 299.
(Yes. 54:17; 62:2-5; Hos. 2:14-22), (2) bangsabangsa lain (Why. 5:9, 10; Yes. 2:4; 11:12).

Gidlestone menunjukkan bahwa "bangsabangsa" secara khusus mengacu pada bangsabangsa lain, sementara "orang-orang" mengacu pada orang Yahudi. ${ }^{54}$

Dalam catatannya, Willmington meyakini bahwa "semua bangsa" yang dinubuatkan ini khusus mengacu pada bangsa-bangsa lain yang diselamatkan pada masa Perjanjian Lama dan pada masa siksaan untuk menjadi warga kerajaan Mesias. ${ }^{55}$ Menurut Ryrie penduduk pemerintahan Mesias ini meliputi umat Yahudi dan non-Yahudi (Yes. 19:24-25). Jadi, "semua bangsa" di sini mengacu pada non-Yahudi generasi pertama yang membentuk ras dalam milenium. ${ }^{56}$

Ungkapan "dan segala bangsa akan berduyunduyun ke sana" memberikan citra yang jelas tentang pentingnya Bait Allah di kota Yerusalem dalam pemerintahan Mesias. Ia juga akan menjadi titik fokus dari umat manusia. Berbeda dengan perairan fisik yang mengalir dari Yerusalem (Za. 14:8) semua bangsa akan berduyun-duyun ke Yerusalem. ${ }^{57}$ Kata "akan berduyun-duyun" (literal "mengalir") adalah ekspresi figuratif yang menunjukkan bahwa mereka akan dikonversi ke agama yang benar. Hal ini mengindikasikan bahwa mereka akan datang dalam jumlah yang banyak seperti aliran sebuah sungai besar.

Ide dari bangsa-bangsa "berduyun-duyun atau mengalir" atau gerakan dari orang banyak terhadap suatu obyek seperti yang luas adalah salah satu yang sangat besar dan luhur; bandingkan Mazmur 65:7. Hal ini tidak dapat dipahami dari periode sebelumnya ke pembentukan Injil. Tidak pernah ada waktu dari sejarah Yahudi di masa lampau di mana peristiwa nubuatan ini digenapi secara lengkap. Ekspresi ini jelas merujuk kepada periode di tempat lain yang

${ }^{54}$ R. B. Girdlestone, Synonym of the Old Testament (Grand Rapids: William B.Eerdmans, 1956), 256.

${ }^{55}$ Ibid, 300.

${ }^{56}$ Charles C. Ryrie, Teologi Dasar, Jil. 2 (Yogyakarta: ANDI Offset, 1992), 319.

${ }^{57}$ Sailhamer, "Evidence from Isaiah 2", 90. 
sering diprediksi oleh nabi Yesaya ini ( Yes.11:10, $42: 1,6,49: 22 ; 54: 3,60: 3,5,10,62: 2,66: 12,19)$, ketika "bangsa-bangsa" akan dibawa ke pengetahuan yang benar tentang agama.

\section{Dampak-Dampak Pemerintahan Kristus $(2: 3 b-4)$}

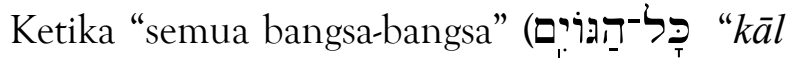
haggōwyim") berduyun-duyun menuju Yerusalem, mereka akan mendorong satu sama lain untuk pergi ke Bait Suci. Allah Israel akan diakui sebagai Tuhan dan Ia akan dijumpai oleh bangsa-bangsa. Dalam Perjanjian Lama, bangsa Israel melakukan ziarah ke Yerusalem tiga kali dalam setahun, tapi di masa depan seluruh dunia akan pergi ke sana. Pada hari itu, instruksi Yahweh akan keluar dari Yerusalem sampai ke ujung bumi (Yes. 2:3). Yerusalem akan menjadi ibukota Kerajaan Mesias saat itu. ${ }^{58}$ Ia akan menghakimi semua orang, dan orang-orang akan hidup dalam damai (Yes. 2:4). Dan ada suatu pemberontakan terhadap kekuasaan Mesias pada akhir Milenium (Lih. Why. 20:7-10), tetapi ini akan melibatkan orang-orang kafir berperang melawanNya, bukan antar bangsabangsa.

Terjadi Pengenalan yang Penuh akan Allah (ay. 3b)

Pengenalan yang penuh tentang Tuhan akan meliputi seluruh bumi ("semua bangsa-bangsa") selama masa milenium - suatu gambaran mengagumkan dari berkat pemerintahan Kristus yang di Sion itu. "Semua bangsa-bangsa" akan ke Yerusalem untuk menerima pengajaran Kristus. Kepergian mereka ke Yerusalem didorong suatu "keinginan" mencari atau menyembah Allah yang benar. Hal ini nyata melalui konstruksi kalimat

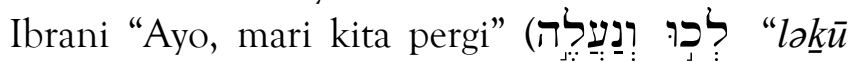
wəna ăleh") mengungkapkan keinginan dengan sebuah tujuan. ${ }^{59}$

\footnotetext{
${ }^{58}$ John F. Walvoord, Israel in Prophecy, 121.

${ }^{59}$ J. Gibson, Davidson's Introduction Hebrew Grammar and Syntax, Edinburgh UK: T \& T Clark, 1994), 106.
}

Dalam kalimat selanjutnya dinyatakan bahwa tujuan bangsa-bangsa pergi ke Yerusalem adalah mereka ingin belajar dari Kristus sendiri. Dari sanalah Tuhan mengajar mereka. Hal ini

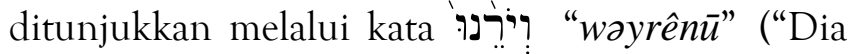
akan mengejar kita”). Sebelumnya, kata ini dipakai untuk menggambarkan aktivitas imam yang mengajar raja-raja (2 Raj. 12:2) dan Musa yang akan mengajar Israel untuk menaati hukum Taurat. ${ }^{60}$ Namun di masa depan dalam Pemerintahan Mesias, Allah sendiri yang akan mengajar secara langsung, tidak hanya kepada Israel tetapi meluas kepada semua bangsa.

Hasil dari pengajaran di Yerusalem dinyatakan

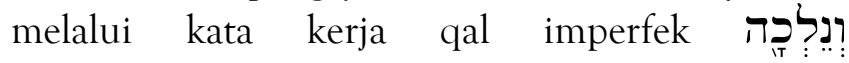
"wənêlək̄āh" (TB. "Kita akan menempuhnya"). ${ }^{61}$ NET mengartikannya "Kita akan mengikuti standar-standarNya." Sedangkan KJV mengartikannya "we will walk in his paths." Apa pun terjemahan yang dipilih, intinya, pada saat itu apa yang mereka pelajari akan menghasilkan tindakantindakan konkrit. Mereka tidak hanya belajar dan kemudian melupakannya. Tetapi pengajaranNya meresap ke dalam hati bangsa-bangsa dan kemudian pada gilirannya menghasilkan perilakuperilaku baru yang cocok dengan standar-standar Allah.

Komentar yang sangat baik mengenai konteks ini disampaikan oleh J. Dwight Pentecost yang mengatakan bahwa, pekerjaan Sang Raja akan membuat warga kerajaanNya memperoleh pengenalan penuh. Tak diragukan lagi akan ada pelayanan mengajar yang tidak ada bandingnya. Pengenalan akan Allah ini akan terjadi melalui pengajaran yang berasal dari Sang Raja (Yes. 2:2, 3; $12: 3-6 ; 25: 9 ; 29: 17-24 ; 30: 20,21 ; 32: 3,4 ; 49: 10$; 52:8; Yer. 3:14, 15; 23:1-4; Mik. 4:2). ${ }^{62}$

${ }^{60}$ William L. Holladay, "ירה" dalam A Concise Hebrew and Aramic Lexicon of the Old Testament, 144.

${ }^{61}$ Chisholm, Exegesis, 110. Hubungan sintaksis antara

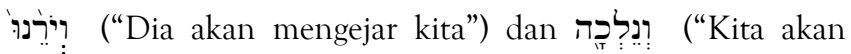
berjalan”) adalah salah satu hasil.

${ }^{62}$ J. Dwight Pentecost, Things to Come (Dunham Press, 1959), 487-490. 
Dosa Bangsa-bangsa Dihakimi (ay. 4a)

Salah satu peranan Kristus atas bangsa-bangsa yang ada dalam pemerintahanNya adalah "Ia akan menjadi hakim" (ְִ⿱ Pengertian utama kata tersebut adalah untuk melaksanakan proses pemerintahan yang berfungsi sebagai yudikatif yang memutuskan perkara. ${ }^{63}$ Kata ini menunjuk pada tindakan-tindakan Kristus dalam pemerintahanNya yang tidak hanya menyatakan otoritas atas bangsa-bangsa secara menyeluruh, tetapi Ia akan dengan adil memutuskan kontroversi, diskriminasi antara individu-individu, pertanyaan-pertanyaan politik, masalah domestik dan agama sipil. ${ }^{64}$ Nuansa yang sama dari peran Kristus atas bangsa-bangsa yang

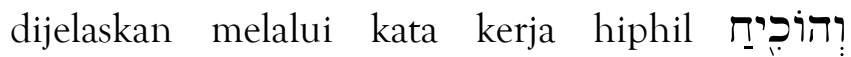
"wəhōwkîah" "akan menjadi wasit, menghakimi, memarahi, membetulkan."

Namun, secara teologis kata ini menekankan peran peradilan Kristus yang akan dimainkan. Dimana Ia akan menghakimi dunia dari tahta-Nya di Bait Allah (Yeh. 43:1-12). Kristus akan menghakimi perilaku berdosa manusia. Hanya orang-orang percaya akan memasuki milenium (Mat. 25:31-46, Yeh. 20:33-38), tetapi mereka akan memiliki anak yang lahir dalam dosa (Za. 14:1619). ${ }^{65}$ Sifat berdosa menghasilkan tindakan dosa. Perbuatan dosa harus dihakimi-pada konteks inilah kata šăfat itu harus dipahami.

\section{Situasi Damai Akan Terwujud (4c)}

Salah satu hasil dari pemerintahan Kristus itu adalah kedamaian. Senjata-senjata tidak difungsikan sebagai alat peperangan. Tetapi diubah menjadi alat pertanian yang menyatakan kemakmuran. Perhatikan "pedang-pedang"

\footnotetext{
${ }^{63}$ Robert D. Culver, "šāfaț," dalam Theological Wordbook of the Old Testament, peny., R. L. Harris, G. L. Archer, dan B. K. Waltke (Chicago: Moody Press, 1980).

${ }^{64}$ Brown, Driver, Briggs, a Hebrew- English Lexicon of the Old Testament (Oxford: Clarendon Press, 1908), 1047.

${ }^{65}$ J. F. Walvoord, The Millenial Kingdom, (Grand Rapids MI: Zondervan, 1959), 302.
}

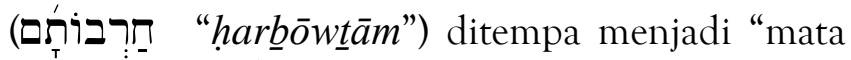

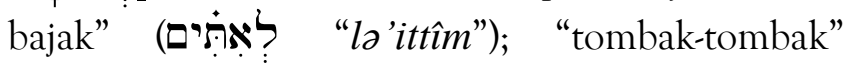
("wahănîtōwtêtêhem") menjadi "pisau pemangkas " (לִ "lamazmêrōwt”"). Ini merupakan panorama yang penuh kedamaian.

Sebagai akibat kebenaran, kerajaan milenium menjadi suatu masa kedamaian. Tidak ada lagi konflik antara bangsa-bangsa dan seluruh dunia akan menjadi damai (Yes. 2:4). Dalam masa ini damai sejahtera secara individu dan nasional akan terwujud sebagai hasil dari pemerintahan Mesias. Pendamaian akan datang bukan dengan prestasi manusia, tetapi karena kehadiran Allah dan peran Kristus di Yerusalem. Pada waktu itu Israel akan dipenuhi dengan roh Allah (Yeh. 36:24-30) dan dosa-dosanya akan diampuni (Yer. 31:31-34). ${ }^{66}$

Frase terakhir berbunyi "Mereka tidak akan

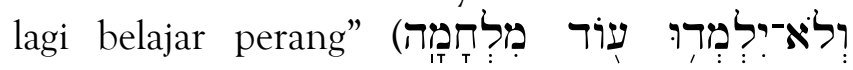
"walō- yilmad̄ $\bar{u}$ 'ōwd milhāmāh"). Di dalam pemerintahan Mesias tidak diperlukan lagi latihan militer, karena sama sekali tidak ada gunanya. Delitzsch merangkum dengan baik ayat ini dengan menyatakan bahwa: "Perdamian akan tercipta secara penuh, tetapi bukan terjadi oleh karena kesepakatan untuk melakukan gencatan senjata, namun sebagai berkat dari pemerintahan Allah." ${ }^{67}$

Pembahasan terhadap "analisa Pemerintahan Mesias dalam Yesaya 2:1-4 memberikan beberapa pengertian bagi pembaca mengenai masa depan Israel. Ayat-ayat tersebut menjelaskan tentang masa depan kerajaan, lokasi, gambaran dan manfaat dari pemerintahan Mesias. Dalam hal ini, penulis akan memberikan beberapa kesimpulan dan saran terkait dengan materi ini.

\section{KESIMPULAN}

Menurut penulis ada 6 (enam) simpulan yang patut didapatkan dalam pembahasan pemerintahan Mesias menurut Yesaya 2:1-4. Pertama,

${ }^{66}$ Marthin, "Isaiah," 1038.

${ }^{67}$ C. F. Keil and F. Delitzsch, "Isaiah," dalam Commentary on the Old Testament, Jil. 7. Electronic Edition STEP Files Copyright (C) 2000. 
pemerintahan Mesias memiliki keterkaitan tentang kedatanganNya. Hal ini dapat ditunjukan dengan ekspresi kedatangan Mesias terutama zaman Mesias, yang sering digunakan dalam Perjanjian Lama dan Perjanjian Baru, untuk menunjuk saat atau waktu. Lihat Kisah Para Rasul 2:17; bandingkan Yoel 2:28; Ibrani 1:2; 1 Petrus 1:5, 20; 1 Yohanes 2:18, kejadian 49:1; Mikha 4:1; Ulangan 4:30; Yeremia 48:47; Daniel 11:28. Jika memerhatikan dalam teks perjanjian baru yang lain, maka Wahyu 20:1-6 memberikan bingkai waktu tentang pemerintahan Kristus di masa depan dalam milenium, yaitu sebuah masa penuh kedamaian dan kemakmuran. Milenium yang diikuti tribulasi (Why. 6-19), dan mendahului langit baru dan bumi baru (Why. 21-22). Banyak ayat dalam Yesaya, termasuk pasal 2:1-4, digenapi secara mendatail dalam kerajaan Milenium (Yes. 9:6-7, 11:1-10, 40:1-11, 61:4-11, 62:1-12, 65:17-25. Jadi, frase "pada hari-hari terakhir" dalam konteks Yesaya 2:1-4, mengacu kepada waktu pemerintahan milenial Kristus di masa depan.

Kedua, penjelasan tentang pusat pemerintahan Mesias. Pusat pemerintahan ini akan terkonsentrasi di Yerusalem. Kota tersebut akan menjadi pusat ibadah untuk dunia. Pada hari-hari terakhir "gunung rumah TUHAN akan didirikan" (ay.2b). Gunung yang menjadi tempat Rumah Tuhan dibangun menunjuk pada gunung Moria, yang disebut gunung rumah TUHAN. Gunung dimana Bait Allah didirikan, akan menjadi objek yang akan mengekspresikan ibadah umum dari Allah yang benar. Dan karenanya, gunung ini akan diangkat lebih tinggi dari semua bukit-bukit atau gunung-gunung lain. Menyembah Allah yang benar akan menjadi obyek begitu mencolok untuk dilihat oleh semua bangsa, di mana semua bangsa akan meniggalkan benda lainnya karena tertarik oleh kemuliaan menyembah Allah yang benar.

Ketiga, mengenai warga kerajaan Mesias. Menurut pembahasan Yesaya 2:1-4, warga kerajaan Mesias ini akan terdiri dari; (1) orang-orang Israel yang sudah diselamatkan dimana mereka dihubungkan dengan Allah melalui perkawinan (Yes. 54:17; 62:2-5; Hos. 2:14-22), (2) bangsa- bangsa lain (Why. 5:9, 10; Yes. 2:4; 11:12). Hal ini juga didukung oleh teks-teks Perjanjian Lama dan Perjanjian Baru mengenai warga kerajaan ketika hadirnya Pemerintahan Mesias.

Keempat, dampak-dampak pemerintahan Mesias. Allah Israel akan diakui sebagai Tuhan, dan Ia akan dijumpai oleh bangsa-bangsa. Dalam Perjanjian Lama, Bangsa Israel melakukan ziarah ke Yerusalem tiga kali dalam setahun, tapi di masa depan seluruh dunia akan pergi ke sana (termasuk semua bangsa). Pada hari itu, instruksi Yahweh akan keluar dari Yerusalem sampai ke ujung bumi (Yes. 2:3). Yerusalem akan menjadi ibukota Kerajaan Mesias pada saat itu. Dari sisi lain, Ia akan menghakimi semua orang, dan orang-orang akan hidup dalam damai (Yes. 2:4). Dan ada suatu pemberontakan terhadap kekuasaan Mesias pada akhir Milenium (Lih. Why. 20:7-10), tetapi ini akan melibatkan orang-orang kafir berberang melawanNya, buka antar bangsa-bangsa.

Kelima, terjadi pengenalan yang penuh akan Allah. Hal ini dapat ditunjukkan dengan Pengenalan tentang Tuhan yang akan meliputi seluruh bumi ("semua bangsa-bangsa") selama masa milenium-suatu gambaran mengagumkan dari berkat pemerintahan Kristus yang di Sion itu. "Semua bangsa-bangsa" akan ke Yerusalem untuk menerima pengajaran Kristus. Kepergian mereka ke Yerusalem didorong suatu "keinginan" mencari atau menyembah Allah yang benar. Pengenalan Allah menghasilkan perilaku-perilaku baru yang cocok dengan standar-standarNya.

Keenam, dosa bangsa-bangsa dihakimi. Artinya bahwa Ia akan menghakimi dunia dari tahta-Nya di Bait Allah (Yeh. 43:1-12). Kristus akan menghakimi perilaku berdosa manusia. Hanya orang-orang percaya akan memasuki milenium (Mat. 25:31-46, Yeh. 20:33-38), tetapi mereka akan memiliki anak yang lahir dalam dosa (Za. 14:1619). Serta yang keenam, adalah situasi damai dalam Pemerintahan Mesias akan terwujud. kerajaan milenium menjadi suatu masa kedamaian. Tidak ada lagi konflik antara bangsabangsa dan seluruh dunia akan menjadi damai (Yes. 2:4). Dalam masa ini damai sejahtera secara 
individu dan nasional akan terwujud sebagai hasil dari pemerintahan Mesias. Pendamaian akan datang bukan dengan prestasi manusia, tetapi karena kehadiran Allah dan peran Kristus di Yerusalem. pada waktu itu Israel akan dipenuhi dengan roh Allah (Yeh. 36:24-30) dan dosadosanya akan diampuni (Yer. 31:31-34).

Kata-kata Yesaya sangat mendorong orangorang percaya masa kini. Yesaya 2:1-4 memberikan suatu nubuatan waktu yang berisi tentang berkat bagi orang Yahudi dan non-Yahudi. Secara praktis, artikel ini memberikan pelajaran tentang pentingnya hubungan yang baik dengan Allah. Pengenalan akan Allah diwujudkan dengan adanya keinginan untuk menyembahNya. Bahkan, melalui pemerintahanNya, orang-orang percaya didorong untuk berjalan dalam terang Tuhan pada hari ini!

\section{KEPUSTAKAAN}

Archer, G. L. A Survey of Old Testament Introduction. Chicago IL: Moody Press, 1994.

Barnes, Albert. Barnes' Note on the Old Testament (Parsons technology, Inc. Cedar Rapids, Iowa. Electronil Edition STEP Files Copyright (C) 1999.

Brown, Driver, Briggs, a Hebrew-English Lexicon of the Old Testament (Oxford: Clarendon Press, 1908.

BHS (Biblia Hebraica Stuttgartensia, $2^{\text {nd }}$ edn, Karl Elliger, and Wilhelm Rudolph, eds, Stuttgat Ger: Deutsche Bibelgesellschaft, 1977.

Bullock, C. Hassel. Kitab Nabi-nabi Perjanjian Lama. Malang: Gandum Mas, 2002.

Culver, Robert D. ““š fa\%o," dalam Theological Wordbook of the Old Testament, peny., R. L. Harris, G. L. Archer, dan B. K. Waltke. Chicago: Moody Press, 1980.

Delitzsch, F. Isaiah: Commentary on the $\mathrm{Ol}$ Testament. Jil. 7. Peny., C. F. Keil, dan F. Delitzch. Reprint Peabody MA: Hendrickson, 1996.
Feinberg. C. The Minor Prophets. Chicago IL: Moody Press, 1990.

Gray, George Buchanan. A Critical and Exegetical Commentary in the Book of Isaiah I-XXVII. Edinburgh: T\&T Clark, 1912.

Gibson, J. Davidson's Introductory Hebrew Grammar and Syntax. Edinburgh UK: T\&T Clark, 1994.

Girdlestone, R. B. Synonyms of the Old Testament, Grand Rapids MI: William B. Eerdmans, 1956.

Grogan, G. W. "Isaiah,” dalam The Expositor's Bible Commentary. Jil. 6. Peny. F. Gaebelein. Grand Rapids MI: Zondervan, 1978.

Holladay, William L. A Concise Hebrew And Aramic Lexicon of The Old Testament.

Kaiser, William L. A Concise Hebrew And Aramic Lexicon of the Old Testament.

Kidner, Derek. Tafsiran Alkitab Masa Kini 2 "Yesaya". Jakarta: Yayasan Komunikasi Bina Kasih, 1985.

Klein, William W. Craig Blomberg, dan Robert L. Hubbard, Introduction to Biblical Interpretation 2. Malang: Literatur SAAT, 2013.

Lange, J. P. Isaiah: Commentary of the Holy Scriptures. Grand Rapids MI: Zondervan, 1877. Program CD-ROM, Quick verse 2010.

Leupold, H. C. Exposition of Isaiah. Jil 1. Grand Rapids: Baker House, 1971.

Longman III, Tremper. Making Sense of the Old Testament. Malang: Literatur SAAT, 2012.

Martin, J. A. Isaiah: The Bible Knowledge Commentary Old Testament, peny., J. F. Walvoord, and R. B. Zuck. Wheaton IL: Victor Books, 1994.

Motyer, J. Alec. "The Prophecy of Isaiah.” Dalam Analysed Bible. Downers Grove IL: IVP, 1993.

Osborne, Grant R. Spiral Hermeneutika: Pengantar Komprehensif Bagi Penafsiran Alkitab. Surabaya: Momentum, 2012. 
Pentecost, J. Dwight. Things to Come. Dunham Press, 1959.

Ryrie, Charles C. Teologi Dasar, Jil. 2. Yogyakarta: ANDI Offset, 1992.

Sailhamer, J. H. "Evidence from Isaiah 2" Dalam A Case for Premillennialism: A New Consensus, D. K. Campbell, and J. L. Townsend, eds, Chicago IL: Moody Press, 1992.

Stuart, Douglas. Eksegese Perjanjian Lama. Malang: Gandum Mas, 2012. dan Gordon D. Fee, HermeneutikMenafsirkan Firman Tuhan Dengan Tepat Malang: Gandum Mas, 2011.

Sualang, Farel Yosua. "Prinsip-prinsip Hermeneutika Genre Hikmat Dalam Kitab Amsal: Suatu Pedoman Eksegesis.” (2019). INA-Rxiv. May 9. https://osf.io/preprints/inarxiv/xmk6h/ (diakses 29 April 2020)

Teshner, Achim, Rangkaian Visi Mutiara Kitab Yesaya. Jakarta: Yayasan Komunikasi Bina Kasih, 1996.

Waltke, B. K., M. O'Connor, An Introdction to Biblical Hebrew Syntax. Wihona Lake IN: Eisenbrauns, 1990. "Obadiah, Jonah, Micah," dalam Tyndale OT Commentary, Peny., D. J. Wiseman. Downers Grove IL: IVP, 1998.

Walvoord, J. F. The Millenial Kingdom. Grand Rapids MI: Zondervan, 1959.

Willmeington, H. L. Eskatologi. Malang: Gandum Mas, 2003.

Wood, Leon J. The Prophets of Israel. Malang: Gandum Mas, 2005.

Young, E. J. The Book of Isaiah. Jil. 3. Grand Rapids MI: William B. Eerdmans, 1996.

Zuck, Roy .B. Hermeneutik: Basic Bible Interpretation. Malang: Gandum Mas, 2014. 